\title{
HISTOLOGY AND HISTOCHEMISTRY OF THE MALE ACCESSORY GLANDS OF THE RED DEER, CERVUS ELAPHUS L
}

\author{
ELIZABETH AUGHEY \\ Department of Histology and Embryology, \\ University of Glasgow Veterinary School \\ (Received 29th March 1968, revised 5th Fune 1968)
}

\begin{abstract}
Summary. The presence of a disseminate prostate is described in the red deer stag. The glands are divided into cranial and caudal groups on a histochemical basis; the cranial glands are considered to produce a mucoprotein and fat, the caudal glands a glycolipid. The latter are affected by season, and hence by the endocrine status of the stag, only becoming active during the rut when the testicular interstitial cells are active. The cranial glands are only minimally affected by season.

The histological and histochemical changes in the seminal vesicle of the pre-rutting and rutting deer stag are described. The presence in the secretory epithelium of the rutting red deer stag seminal vesicle of a complex carbohydrate, phospholipid and fat is shown.

The testicular interstitial cells show marked variations from a fibroblast appearance in the pre-rut to a highly reactive cell in the rut.
\end{abstract}

\section{INTRODUCTION}

Some years ago, two reports by Wislocki $(1943,1949)$ described the seasonal changes which take place in the testes, epididymides and seminal vesicles of Virginia deer (Odocoileus virginianus borealis) and Japanese deer (Cervus nippon); mention was also made of urethral glands considered to be accessory prostate/ bulbo-urethral tissue, but these were not described.

In view of the presence of a disseminate prostate in the ruminant, when the opportunity to study red deer on the Rhum Nature Reserve was afforded, specimens of the genital tract were examined histologically and histochemically and some comparisons made over a period of 3 months-August, September and October. This allowed a further investigation into the changes in activity which normally take place at this season, August representing immediate prerut and late September/October covering the rut.

\section{MATERIAL AND METHODS}

The material consisted of the testes, ampullae, seminal vesicles and urethrae of fourteen adult red deer culled from a free-running herd (see Table 1). 
Sections were prepared from tissues fixed in Baker's calcium formol, absolute ethanol, 10\% neutral formalin and Elftman's fixative (1958). Tissues were fixed in the field on a personal visit or sent from Rhum in fixative; the entire male genital tract was placed in a plastic bag with some crude formalin within a few hours of death.

TABLE 1

DETAILS OF RED DEER STAGS EXAMINED

\begin{tabular}{|c|c|c|c|c|c|}
\hline \multirow{2}{*}{$\begin{array}{c}\text { Reference } \\
\text { number }\end{array}$} & \multirow{2}{*}{$\begin{array}{c}\text { Date shot } \\
1962\end{array}$} & \multirow{2}{*}{$\begin{array}{c}\text { Age } \\
\text { (years) }\end{array}$} & \multicolumn{2}{|c|}{ Antlers } & \multirow{2}{*}{$\begin{array}{l}\text { Body } \\
\text { weight } \\
(\mathrm{kg})\end{array}$} \\
\hline & & & No. of points & State & \\
\hline $\begin{array}{l}1438 \\
1444 \\
1445 \\
1450 \\
1451 \\
1527 \\
1535 \\
1536 \\
1539 \\
1540 \\
1541 \\
1543 \\
1544 \\
1526\end{array}$ & $\begin{array}{c}\text { 21st August } \\
\text { 23rd August } \\
\text { 23rd August } \\
\text { 27th August } \\
\text { 27th August } \\
\text { 20th September } \\
\text { 27th September } \\
\text { 27th September } \\
\text { 4th October } \\
\text { 4th October } \\
\text { 9th October } \\
\text { 12th October } \\
\text { 16th October } \\
\text { 20th October }\end{array}$ & $\begin{array}{r}4 \\
4 \\
4 \\
2 \\
6 \\
6 \\
4 \\
6 \\
4 \\
4 \\
4 \\
11 \\
4 \\
9\end{array}$ & $\begin{aligned} 4 \\
8 \\
7 \\
4 \\
8 \\
8 \\
7 \\
9 \\
10 \\
6 \\
6 \\
5 \\
\\
11\end{aligned}$ & $\begin{array}{l}\text { In velvet } \\
\text { In velvet } \\
\text { Clean } \\
\text { In velvet } \\
\text { Clean } \\
\text { Clean } \\
\text { Clean } \\
\text { Clean } \\
\text { Clean } \\
\text { Clean } \\
\text { Clean } \\
\text { Clean } \\
\text { mel } \\
\text { Clean }\end{array}$ & $\begin{array}{c}60 \\
60 \cdot 8 \\
75 \cdot 8 \\
43 \cdot 8 \\
80 \\
84 \\
72 \\
103 \cdot 4 \\
86 \cdot 6 \\
73 \cdot 6 \\
58 \cdot 1 \\
72 \cdot 1 \\
75 \cdot 6 \\
117 \cdot 2\end{array}$ \\
\hline
\end{tabular}

Data supplied by courtesy of V. P. W. Lowe, Merlewood Research Station, Grangeover-Sands, Lancs.

Paraffin sections were cut at $5 \mu$ and stained routinely with haematoxylin and eosin, Gomori's trichrome (Gomori, 1950), amido black (Puchtler \& Leblond, 1958), and methyl green pyronin; this was repeated following incubation for $30 \mathrm{~min}$ at $37^{\circ} \mathrm{C}$ in ribonuclease. Further sections were stained to demonstrate polysaccharides using the periodic acid-Schiff (PAS) technique (McManus, 1946); this was repeated following incubation for $15 \mathrm{~min}$ at $37^{\circ} \mathrm{C}$ in diastase, alcian blue (Mowry, 1956) either alone or with PAS (Gomori, 1952), Southgate's mucicarmine, toluidine blue (at $\mathrm{pH}$ values from 3 to 5) and celestine blue. Baker's acid haematein was used to demonstrate phospholipids in tissues fixed in Elftman's fixative or post-chromed following fixation in Baker's calcium formol or $10 \%$ neutral formalin. Sections were also stained with Heidenhain's iron haematoxylin for nuclear detail and mitochondria. Frozen sections were cut at $10 \mu$ and stained with sudan black B and burnt sudan black B (Berenbaum, 1958) oil red $O$ and toluidine blue (Arvy, 1958), and nile blue sulphate. Sections of testes were also stained to illustrate the presence of carbonyl groups (Ashbel \& Seligman, 1949).

\section{RESULTS}

\section{Anatomical observations}

The accessory sex glands of the stag appeared to consist only of paired ampullae and seminal vesicles; neither compact prostate nor bulbo-urethral glands 
could be discerned. The ampullae measured 5 to $6 \mathrm{~cm}$ by $0.6 \mathrm{~cm}$. The seminal vesicles were roughly conical, corrugated masses 5 to $6 \mathrm{~cm}$ long and varying in width from $1 \mathrm{~cm}$ at the free end to $1.6 \mathrm{~cm}$ at the thickest part; a slight reduction in width occurred at the point of union with the urethra and here the two glands were joined by a ligament-like band. The pelvic urethra was a straight thick-walled tube $5.5 \mathrm{~cm}$ long; as it curved round the pelvic brim it was surrounded by the prominent $\mathrm{m}$. bulbo-urethralis.

\section{Histological observations}

The pelvic urethra. Throughout most of its length the pelvic urethra was lined by a transitional epithelium some six to eight cells deep but there were occasional patches where it became stratified columnar. Dorsally, near its origin, the ejaculatory ducts and seminal vesicles opened separately (Pl. 1, Fig. 1). These lost their muscle coat before penetrating the urethral wall and here were surrounded by concentrically disposed collagen fibres.

Numerous peri-urethral glands forming a disseminate prostate (cf. domestic ruminants) were found in the propria adjacent to the muscle and between this and the urethral epithelium throughout most of the pelvic urethra was a plexus of large sinusoidal blood spaces. The glands were simple branched tubules showing a distinct lobulation where they were most abundant (Pl. 1, Figs. 2, 3 and 4) and opened separately into the urethra. Glands in the first centimetre or so of the urethra were lined by tall columnar cells with intensely eosinophilic cytoplasm and appeared to be little affected by season changes (P1. 1, Fig. 2); glands caudal to these in the pre-rut specimen had a low cuboidal epithelium (Pl. 1, Figs. 3 and 4a) which became tall columnar during the rut (P1. 1, Fig. 4). Histochemical observations (see below) confirmed the finding that there were distinct cranial and caudal groups of glands.

A layer of obliquely orientated smooth muscle limited the proprial glandular zone peripherally and was particularly thick at anterior levels; some muscle fibres extended amongst the more peripheral gland tubules. Caudally this muscle diminished until it consisted only of a few fibres scattered amongst the glands. A dorsal midline septum of smooth muscle and connective tissue, partially dividing the glandular tissue into right and left parts, extended from about the 2nd to the 5 th $\mathrm{cm}$ of the urethra. External to the smooth muscle coat was a thick layer of apparently circular skeletal muscle fibres. This was most prominent on the ventral and lateral aspects; dorsally, at some levels, it was replaced by a midline septum of smooth muscle and connective tissue. External to the muscle there was an adventitia consisting of a thick layer of areolar tissue with numerous fat cells, blood vessels and nerves.

Seminal vesicles. These were compound tubular glands with a thick capsule containing much smooth muscle which could be resolved into inner circular and outer longitudinal layers interspersed with numerous oblique fibres; connective tissue was prominent between the muscle bundles. Septae of connective tissue and smooth muscle divided the parenchyma into lobes and lobules and were particularly prominent in specimens of August deer (Pl. 2, Fig. 5); a marked increase in the amount of glandular tissue in October deer is accompanied by a corresponding decrease in the interglandular tissue (Pl. 2, Fig. 6). 
In specimens obtained in August, the gland tubules had wide lumina and were lined by a two-layered epithelium consisting of a superficial columnar layer with an uneven surface (average height $15 \mu$ ) and numerous basal cells. In specimens obtained in October, the amount of glandular tissue was much increased, the epithelium taller (average height $40 \mu$ ) with a more uneven surface. The basal cells appeared to form a complete layer at this time also. Amorphous masses of inspissated secretion were present in the gland tubules in deer obtained in both August and September but were rare in specimens obtained in October.

Ampullae. Here the mucosa was much folded and gland-like and was lined by a pseudostratified columnar epithelium the cells of which showed blebbing and a ragged luminal surface; stereocilia were absent (Pl. 2, Fig. 7). The lumina of the gland-like spaces in the October specimen contained glandular material mixed with spermatozoa; even in August specimens, a few spermatozoa were found and, at this time also, amorphous masses of inspissated secretion were common. The smooth muscle coat was thick and irregular although bundles of circular, longitudinal and oblique fibres could be distinguished, the peripheral bundles particularly being separated by thick strands of connective tissue.

Testes. In the pre-rut testes, the seminiferous tubules were lined by a single layer of large pale cells with a vesicular nucleus, a spongy cytoplasm and illdefined cell outlines; interspersed with these were small, more darkly-staining cells with a small dark nucleus (Pl. 2, Fig. 8). Wislocki (1943) considered similar cells in Virginia and Japanese deer to be respectively spermatogonia and Sertoli cells. In some tubules meiotic figures were observed, in others the seminiferous epithelium became stratified and a few spermatozoa were found in the vasa efferentia. The majority of the interstitial cells at this time were small and darkly staining with the general appearance of fibroblasts (Pl. 2, Fig. 8).

During the rut, testicular tubules exhibited active spermatogenesis, and interstitial cells were markedly increased in size and number with a deeply-staining granular cytoplasm in which a clearly defined centrosome could be seen in the juxtanuclear position (Pl. 2, Fig. 9). The small dense nucleus is eccentrically

\section{EXPLANATION OF PLATE 1}

FIG. 1. Transverse section of stag urethra (U) at its origin with the excretory ducts of the seminal vesicles (sv) immediately dorsal to the urethral lumen, and the ductuli deferentes (dd) dorsal and lateral again. The peri-urethral gland tubules $(\mathrm{dp})$ are mainly dorsal, spreading laterally. The heavy skeletal muscle (M) coat of the urethra is much in evidence. $\mathrm{H}$ and $\mathrm{E}, \times 5$.

FIG. 2. Cranial peri-urethral glands of the pre-rut stag. The eosinophilic tall columnar epithelium cells have basal nuclei. Occasional strands of smooth muscle $(m)$ can be seen between the gland tubules. $\mathrm{H}$ and $\mathrm{E}, \times 120$.

Fig. 3. Caudal peri-urethral glands ( $p$ ) of the pre-rut stag form compact lobules in the peripheral lamina propria. Note the numerous sinusoidal blood vessels $(\mathrm{s})$. $\mathrm{sm}-\mathrm{smooth}$ muscle; $M-$ skeletal muscle. $\mathrm{H}$ and $\mathrm{E}, \times 30$.

Fic. 4. Caudal peri-urethral glands of the rutting stag illustrate the active secretory epithelium compared with the inactive, quiescent pre-rut appearance. The secretory cell cytoplasm stains darkly with haematoxylin and eosin; the sinusoids contain blood (S), cf. Fig. $4 \mathrm{a}$. $\mathrm{H}$ and $\mathrm{E}, \times 74$.

Fig. 4a. Caudal peri-urethral glands of the pre-rut stag. $\mathrm{H}$ and $\mathrm{E}, \times 74$. 

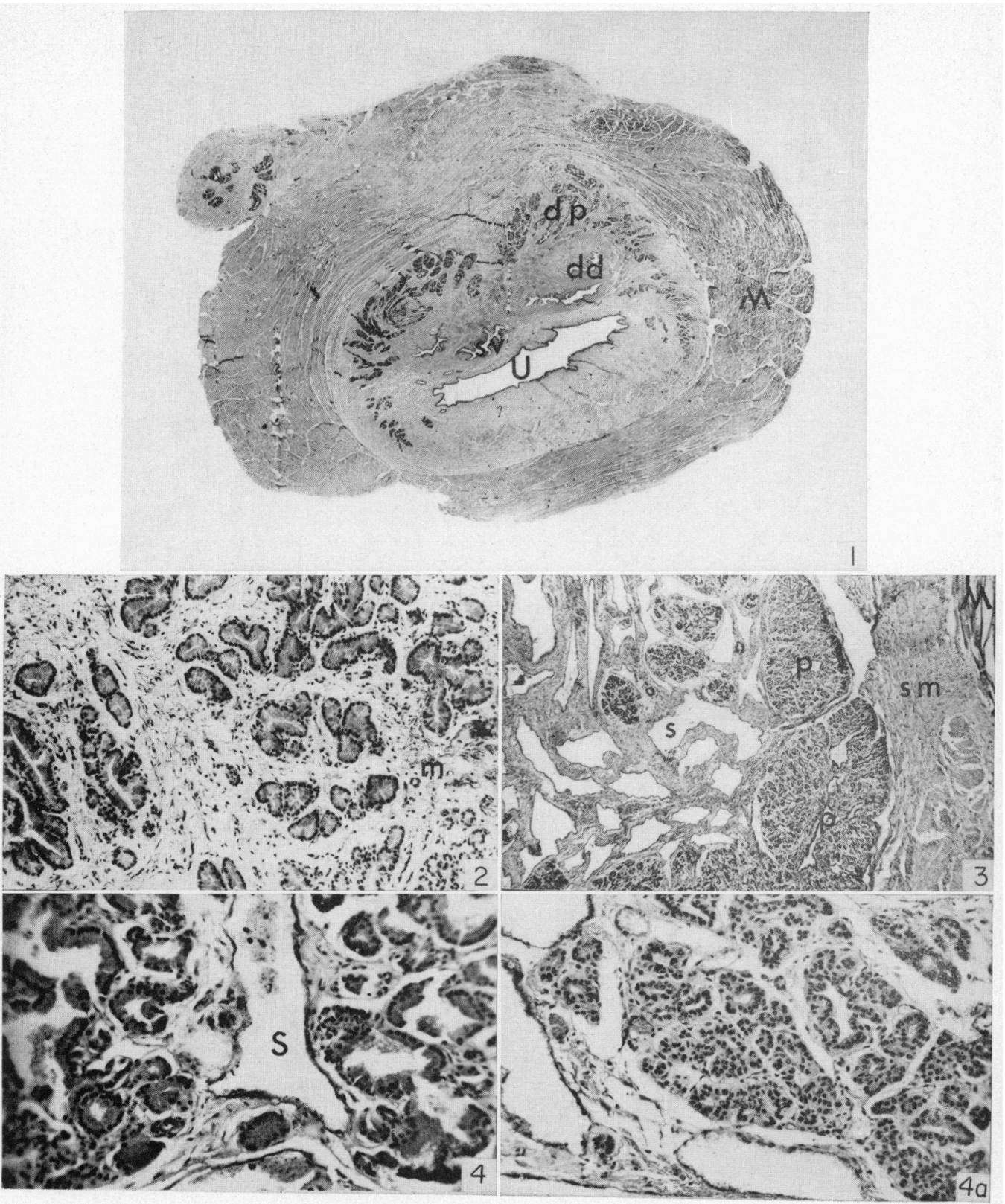
PIATE 2

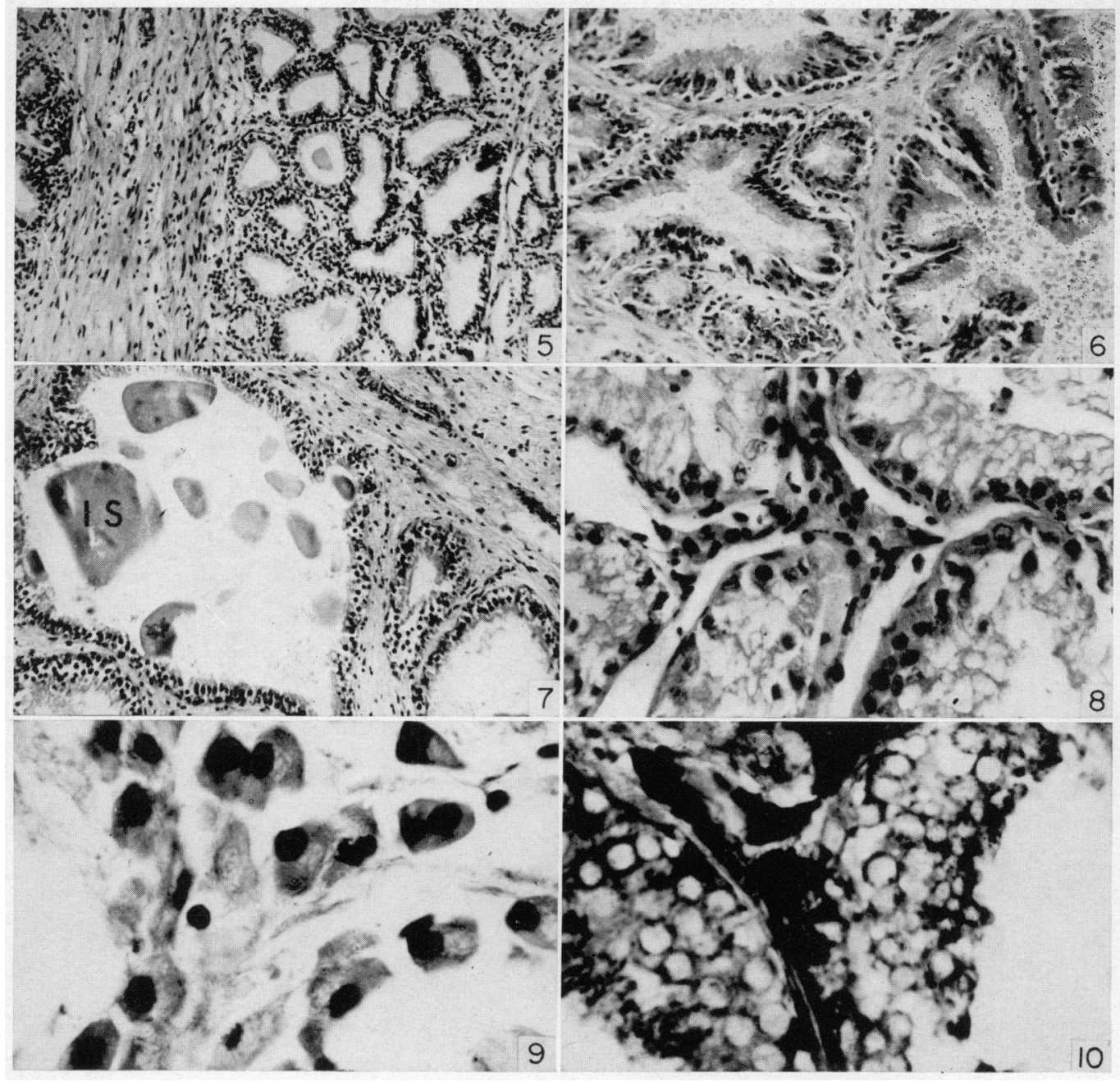

FIG. 5. Stag seminal vesicle in August illustrates the numerous small alveoli lined by low columnar cells and separated by thick strands of inter-alveolar connective tissue. Inspissated secretion masses are occasionally present. $\mathrm{H}$ and $\mathrm{E}, \times 120$.

Fic. 6. Illustrates the marked change in the secretory cells of the seminal vesicle in rut. The tall columnar lining epithelium is very reactive, free secretion is present in the alveoli, and the connective tissue strands between the alveoli are markedly reduced. $\mathrm{H}$ and $\mathrm{E}$, $\times 74$.

FIg. 7. Illustrates the pseudostratified epithelium of the ampulla, and the inspissated masses of secretion (IS) commonly in the pre-rut and rutting stag. $\mathrm{H}$ and $\mathrm{E}, \times 120$.

FIG. 8. Testis before rut. The seminiferous tubules are lined only by a single layer of cells and the specific interstitial cells (Leydig) are small. $\mathrm{H}$ and $\mathrm{E}, \times 450$.

Fig. 9. Leydig cells from the testis of a stag in rut. These are large with abundant granular cytoplasm and a juxtanuclear vacuolated area. $\mathrm{H}$ and $\mathrm{E}, \times 1200$.

FIG. 10. Illustrates the high fat content of the Leydig cells during the rut. Sudan black, $\times 450$. 
disposed. The diameter of the seminiferous tubules was measured in three August, one September and two October stags, and may be related to body weight and antler points (Table 2).

TABLE 2

AVERAGE DIAMETER OF THE SEMINIFEROUS TUBULES IN RELATION TO BODY WEIGHT AND THE STATE OF THE ANTLERS

\begin{tabular}{|c|c|c|c|c|c|c|}
\hline \multirow{2}{*}{$\begin{array}{l}\text { Reference } \\
\text { number }\end{array}$} & \multirow{2}{*}{$\begin{array}{c}\text { Date shot } \\
1962\end{array}$} & \multirow{2}{*}{$\begin{array}{c}\text { Age } \\
\text { (years) }\end{array}$} & \multirow{2}{*}{$\begin{array}{l}\text { Weight } \\
(\mathrm{kg})\end{array}$} & \multicolumn{2}{|c|}{ Antlers } & \multirow{2}{*}{$\begin{array}{c}\text { Diameter of } \\
\text { the seminiferous } \\
\text { tubules }(\mu)\end{array}$} \\
\hline & & & & No. of points & State & \\
\hline $\begin{array}{l}1445 \\
1444 \\
1450 \\
1536 \\
1544 \\
1526\end{array}$ & $\begin{array}{l}\text { 23rd August } \\
\text { 23rd August } \\
\text { 27th August } \\
\text { 27th September } \\
\text { 16th October } \\
\text { 20th October }\end{array}$ & $\begin{array}{l}4 \\
4 \\
2 \\
6 \\
4 \\
9\end{array}$ & $\begin{array}{r}75 \cdot 8 \\
60 \cdot 8 \\
43 \cdot 8 \\
103 \cdot 4 \\
75 \cdot 6 \\
117 \cdot 2\end{array}$ & $\begin{array}{ll}4 & \\
8 & \\
4 & \\
9 & \\
& \text { Hum }\end{array}$ & $\begin{array}{l}\text { In velvet } \\
\text { In velvet } \\
\text { In velvet } \\
\text { Clean } \\
\text { ael } \\
\text { Clean }\end{array}$ & $\begin{array}{l}250 \\
300 \\
250 \\
270 \\
260 \\
300\end{array}$ \\
\hline
\end{tabular}

\section{Histochemical observations}

Peri-urethral glands. The secretory epithelium of the cranial group of glands was composed of tall columnar cells with an intensely eosinophilic cytoplasm filled with supranuclear granules which stained intensely with PAS. This reaction was unaffected by prior incubation with diastase. The granules were not stained with alcian blue and did not exhibit metachromasia with either methylene blue or toluidine blue ( $\mathrm{pH} 3.5$ to 4.5 ), although they were positive with Southgate's mucicarmine. Secreted material in the gland lumina reacted similarly. Both amido black and ninhydrin Schiff-stained cytosomal granules appeared to be similar in distribution to the PAS-positive granules but were larger; some of these appeared to lie outside the cell in the gland lumen. The cytosomal granules were also pyronin-positive and this reaction could be prevented by prior incubation with ribonuclease. Lipase material staining with sudan black and sudan IV could be demonstrated in the basal cytoplasm of frozen sections. This corresponded to the Baker's acid haematein reaction.

There was no significant difference in the reactions of glands obtained during pre-rut and rut periods, the principal change apart from the inter-alveolar connective tissue being a slight decrease in the concentration of secretory granules in the cytoplasm of the pre-rut glands.

The caudal peri-urethral glands appeared to be more affected by season than the above. In the pre-rut period, only the cells of occasional tubules reacted with PAS and Southgate's mucicarmine. During the rut cytosomal granules of the secretory cells reacted strongly with PAS, even after prior incubation with diastase, and with Southgate's mucicarmine, but only occasional cells contained granules which stained with amido black and ninhydrin Schiff. Occasional pyronin-positive granules which could be removed by prior ribonuclease incubation were also present. In frozen sections, a sudan black staining material extended throughout the cytoplasm, with a corresponding positive Baker's acid haematein. Heidenhain's iron haematoxylin gave very slight positive results. 
Seminal vesicles. The seasonal changes which occur in the seminal vesicles are marked. In the pre-rut period, some diastase-resistant PAS cytosomal granules could be distinguished in the supranuclear cytoplasm. Mucicarmine gave negative results except in the main excretory duct, where some of the lining cells were stained; secretion in the lumen was also reactive. The basal cytoplasm was pyronin-positive and ribonuclease-labile. Some amido black-positive granules were also present. Perinuclear lipid droplets which stained with oil red $O$, sudan black and sudan IV were also present, together with a few small scattered droplets in the supranuclear cytoplasm.

During the rut, there was an increase in the number of diastase-resistant PAS-positive granules. Secretory cells were unstained by alcian blue, reaction being confined to some cells lining the large excretory duct and the secretion within the duct lumen which was also metachromatic with celestine blue. Strangely, however, it remained unstained with mucicarmine. Pyronin-positive ribonuclease-labile material was present in the infranuclear cytoplasm as in the pre-rut specimen, but the amido black reaction was more widespread, positive granules being present also in the supranuclear cytoplasm. Sudan-positive lipid granules were also more abundant, extending into the supranuclear cytoplasm which was filled with small fat droplets.

In the ampullae, the histochemical reactions were similar to those occurring in the seminal vesicle. Corpora amylaceae which were commonly found here, exhibited a layering which stained with PAS, alternate layers being PASpositive and PAS-negative (Seaman, 1956).

Testes. During the rut, the interstitial cells reacted strongly with fat stains (Pl. 2, Fig. 10), including sudan black B, sudan IV, oil red $O$ and nile blue sulphate, getting a mauve reaction with the latter. Ashbel \& Seligman's (1949) staining method for carbonyl groups also gave a positive reaction. Similar reactions were not given by the small dark cells of the pre-rut gland.

\section{DISGUSSION}

The accessory sex glands of the red deer stag consist of seminal vesicles, ampullated ductuli deferentes and peri-urethral glands. Unlike the domestic ruminants, this species lacks glands strictly comparable with the bulbo-urethral, although the peri-urethral glands have been so styled. Wislocki (1943) considered the peri-urethral glands of Virginia and Japanese deer to represent both prostate and bulbo-urethral glands, and did not describe a compact bulbourethral gland comparable to that of the domestic ruminants. No mention was made in his report of separate cranial and caudal groups of peri-urethral glands, and these glands were not considered to be affected by season. In view of the existence of volumetrically comparable peri-urethral glands in the domestic ruminants, in addition to the compact bulbo-urethral embedded in the $\mathrm{m}$. bulbo-urethralis, it seems more rational to use the terminology common to these species and describe the peri-urethral glands of deer as a disseminate prostate. Cranial and caudal groups of peri-urethral glands have been described in the boar (McKenzie, Millar \& Bauguess, 1938). Aitken (1960), on the other hand, was unable to recognize significant differences between anterior and 
posterior glands in this species. No similar subdivision has been described for the ram (Aitken, 1959) or bull (personal observations).

In this report, cranial peri-urethral glands are described as extending a short distance along the urethra from its origin and as relatively unaffected by season. The eosinophilic cytoplasm of the secretory epithelium reacts strongly with the PAS technique; that this is not glycogen is indicated by the stability of the PAS reaction following treatment with diastase. With mucicarmine, the positive reaction suggests the presence of a more complex polysaccharide (mucopolysaccharide). The positive reactions elicited from the amido black and ninhydrin Schiff techniques indicate a protein. That this protein, in part at least, is ribonucleoprotein is shown by the ribonuclease-labile, pyronin-positive reaction of the secretory granules after methyl green-pyronin. The basally disposed sudanophilic material is distinct from the supranuclear protein/polysaccharide reaction, rather indicating the production of a mucoprotein and fat by the cells. Some of the fat is phospholipid in the positive reaction to the Baker's acid haematein. These findings correspond closely with the histochemical reactions of the boar prostate, also found to secrete a mucoprotein and fat (Aitken, 1960).

The caudal peri-urethral glands are affected by season, the quiescent gland of the pre-rut becoming the markedly active gland of the rut. The secretory epithelial cells of the cranial gland contain diastase-stable, PAS-positive granules which react with mucicarmine. The protein reactions are weak and often absent. Fat droplets are numerous and occur throughout the cell. They consist of phospholipid, rather indicating the production of a glycolipid, which differs from that produced by the ram, boar or dog (Aitken, 1959, 1960; Seaman, 1954), and is quite different from the mucoprotein complex secreted by the cranial glands.

Granules which are PAS-positive and diastase-stable are a constant feature of the seminal vesicle of the red deer, indicating the presence of a polysaccharide which is not glycogen, though presumably the source of fructose known to be present in the roebuck seminal vesicle (Short \& Mann, 1966). This is contrary to Wislocki's findings in Japanese and Virginia deer, where glycogen was a feature of the rut seminal vesicle secretory cell and luminal contents, and was found in the pre-rut secretory cell. In the ram, the PAS-positive substance in the seminal vesicle is diastase-labile, and is the putative source of fructose known to be produced in this gland (Aitken, 1955). In the pig, however, the PAS-positive substance of the seminal vesicle is diastase-resistant (Aitken, 1960), although here, also, a massive production of fructose is known to occur.

The massive amounts of fat in the rut seminal vesicle, as compared with the pre-rut gland, rather indicate an active secretory process unlike the sheep seminal vesicle where fat accumulation by the basal cells demonstrated the castrate appearance (Aitken, 1955). The positive Baker's acid haematein reactions suggest that some of the fat is in the form of a phospholipid; in this respect the seminal vesicle of the red deer stag and the bull are comparable (Cons, 1957).

The changes in the accessory sex glands of the non-rutting stag are comparable to those occurring in the castrated ram and bull and imply a lack of androgen secretion (Aitken, 1959; Trotter, 1959). This is reflected in the 
cytochemistry of the specific testicular interstitial cells where the pre-rut appearance is that of a fibroblast, but the rut reactions indicate a high lipid content, as indicated by the common fat stains, and the presence of carbonyl groups as indicated by a positive Ashbel-Seligman reaction. Brüggemann, Adam \& Karg (1965) reported the sharp increase in ICSH in the 10 weeks before rut; this coincides with the changes apparent in the August testis of the red deer stag, suggesting a gradual build up of interstitial tissue and seminiferous epithelium in preparation for rut. A report of mature spermatozoa in the epididymis of red deer stags in August with full spermatogenesis (Frankenberger, 1953) was not a constant finding in the stags examined here.

The diameter of the seminiferous tubules in the August stags appears to be related to body weight; in the October stags, the hummel is conspicuous in the small diameter of these tubules though spermatogenesis was observed.

A recent report on the sexual cycle of the roebuck (Short \& Mann, 1966) describes the inactive testis of the non-rut with a low testosterone content and small interstitial cells and the active testis of the rut with the high testosterone content and eosinophilic interstitial cells. The seasonal changes described here in the red deer stag are considered to be in accord with the endocrine status of the interstitial cells of the testis.

\section{ACKNOWLEDGMENTS}

I am indebted to R. N. G. Aitken for advice and criticism of the manuscript, to Miss M. Gracie for technical assistance and to Mr A. Finnie for the photographs.

The material was obtained through the good offices of the Nature Conservancy on Rhum, and I am indebted, in particular, to the Warden, Peter Wormell and to V. P. W. Lowe.

\section{REFERENCES}

Artken, R. N. C. (1955) A histochemical study of the seminal vesicle of the sheep. F. Anat. 89, 430.

ArtKen, R. N. G. (1959) Observations on the development of the seminal vesicles, prostate and bulbourethral glands of the ram. F. Anat. 93, 43.

Aitkrn, R. N. C. (1960) A histochemical study of the accessory glands of the boar. F. Anat. 94, 130.

ARvy, L. (1958) Mise en evidence simultanée des lipides figures et des substances métochromatiques. Bull. Microsc. appl. 8, 120.

Ashbel, R. \& Seligman, A. M. (1949) Histochemical demonstration of ketosteroids in normal and neoplastic testes. Endocrinology, 44, 565.

Berenbaum, M. D. (1958) The histochemistry of bound lipids. Q. Fl microsc. Sci. 99, 231.

BrüggemanN, J., Adam, A. \& Karg, H. (1965) ICSH - Bestimungen in Hypophysen von Rehböcken (Capreolus capreolus) und Hirschen (Cervus elaphus) unter Berücksichtigung des Saisoneinflusses. Acta endocr., Copenh. 48, 569.

Cons, D. N. (1957) Some observations on the histology and histochemistry of the seminal vesicles of the bull. F. Endocr. 14, 304.

Elftman, H. (1958) Effects of fixation on lipoid histochemistry. F. Histochem. Cytochem. 6, 317.

Frankenderger, F. (1953) Pohlavni cyklus jelena (Cervus elaphus L.). Čsklá Morf. 1, 28.

Gomori, G. (1950) A rapid one-step trichrome stain. Am. F. clin. Path. 20, 661.

GoMori, G. (1952) Microscopic histochemistry; principles and practice, p. 58. University of Chicago Press.

MaManus, J. F. A. (1946) Histological demonstration of mucin after periodic acid. Nature, Lond. 158, 202.

McKenzie, F. F., Millar, J. C. \& Bauguess, L. C. (1938) The reproductive organs and semen of the boar. Bull. Mo. agric. Exp. Stn, 279. 
Mowry, R. W. (1956) Alcian blue techniques for the histochemical study of acidic carbohydrates. f. Histochem. Cytochem. 4, 407.

PuchtLer, H. \& Leblond, C. P. (1958) Histochemical analysis of cell membranes and associated structures as seen in the intestinal epithelium. Am. F. Anat. 102, 1 .

Seaman, A. (1954) Cytochemical observations on the prostate of the dog. Anat. Rec. 118, 353.

Seaman, A. (1956) Cytochemical observations on corpora amylaceae. 7. Urol. 76, 99.

SHORT, R. V. \& MANN, T. (1966) The sexual cycle of a seasonally breeding mammal, the roebuck (Capreolus capreolus). J. Reprod. Fert. 12, 337.

TROTtER, D. M. (1959) Histological observations of the genitalia of the immature, the castrated and the mature bovine male. Am. J. vet. Res. 20, 213.

WisLockI, G. B. (1943) Studies on the growth of deer antlers. In: Essays in Biology, p. 631. University of Galifornia Press.

WtsLockı, G. B. (1949) Seasonal changes in the testes, epididymis and seminal vesicles of deer investigated by histochemical methods. Endocrinology, 44, 167. 